Originalartikkel

\title{
Samtidig bruk av warfarin, analgetika og antiinflammatoriske midler
}

\begin{abstract}
Sammendrag
Bakgrunn. Det antas at risikoen for blødning øker ved samtidig bruk av warfarin og visse typer analgetika, men det er ukjent i hvor stor grad disse legemidlene kombineres. Hovedhensikten med studien var å kartlegge forekomst av samtidig bruk av warfarin og reseptpliktige analgetika samt antiinflammatoriske midler i Norge.
\end{abstract}

Materiale og metode. Alle pasienter som hentet ut warfarin (Marevan) fra apotek i perioden 2004-06 ble inkludert via Reseptregisteret. Data vedrørende uthenting av paracetamol, svake opioider og NSAID-preparater ble samtidig innhentet. Samtidig bruk ble ansett som sannsynlig dersom ett eller flere av disse legemidlene, forskrevet av én eller flere leger, ble hentet ut i perioden mellom første og siste uthentingsdato for warfarin.

Resultater. Antall warfarinbrukere i Norge var i 2006 i underkant av 80000 (60\% menn), $93 \%$ var eldre enn 50 år og majoriteten av pasientene ble langtidsbehandlet. $25 \%$ av warfarinbrukerne hentet ut svake opioider (tramadol og kodein) i hvert av årene 2004 , 2005 og 2006 , mens $16-23 \%$ og 29-31\% hentet ut henholdsvis NSAIDpreparater og paracetamol alene eller i kombinasjon med kodein.

Fortolkning. Warfarinpopulasjonen er større enn tidligere antatt. Minst en firedel av warfarinbrukerne henter også ut reseptbelagte analgetika eller antiinflammatoriske midler som på ulike måter kan interagere med og øke effekten av warfarin. Dette kan være forbundet med økt blødningsrisiko.
Gro Dahlseng Håkonsen

Avdeling for farmakologi

Institutt for farmasi

Universitetet i Tromsø

Merethe Harjo Pettersen

Institutt for farmasi

Universitetet i Tromsø

\section{Svetlana Skurtveit}

Avdeling for legemiddelepidemiologi

Nasjonalt folkehelseinstitutt

og

Avdeling for samfunnsfarmasi

Institutt for farmasi

Universitetet i Tromsø

Trude Giverhaug

trude.giverhaug@unn.no

Avdeling for farmakologi

Institutt for farmasi

Universitetet i Troms $\varnothing$

9037 Tromsø

Reseptregisteret ble opprettet i 2004 og er et viktig verktøy for å fremskaffe detaljert informasjon om legemiddelbruk på individnivå (1). Antikoagulasjonsmidlet warfarin er det legemidlet i Norge som er forbundet med flest alvorlige bivirkninger. Årlig rapporteres det om 70-80 alvorlige blødninger hos warfarinbrukere, og omtrent halvparten av hendelsene får dødelig utfall (2). Økt kunnskap om brukergruppen og forhold omkring forskrivning og bruk vil være nyttig i arbeidet med å gjøre medisineringen med warfarin sikrere.

Basert på salgstall og antall definerte døgndoser ble det i 2003 anslått å være rundt 50000 warfarinbrukere her i landet (2). Behandlingsmålet for warfarin angis som et definert INR-område (INR; Internatioal Normalized Ratio). Men den individuelle responsen på warfarin er svært varierende, og det kan ofte være utfordrende å holde pasienten stabil i ønsket INR-område (3). Warfarin foreligger $i$ to stereoisomere former, R- og S-warfarin. R-formen metaboliseres i hovedsak av CYP1A2 og S-formen av CYP2C9 og CYP3A4. CYP-aktivitet er bl.a. genetisk bestemt, og samtidig bruk av medikamenter som induserer, hemmer eller er substrater for et gitt CYP-enzym kan endre INR-nivået. Vel så viktig er imidlertid legemiddelinteraksjoner som medfører endret blødningstendens uten å gi utslag på INRverdien. Ulike NSAID-preparater (inkludert acetylsalisylsyre) kan interagere med warfarin både via CYP og via hemming av blodplateaktiviteten, samtidig som disse substansene hemmer cox-1 og dermed oker blødningsrisikoen via hemmet produksjon av mucosa i gastrointestinaltractus (4).
Det er ikke kjent hvilke legemidler som forskrives til warfarinbrukere med behov for analgetisk eller antiinflammatorisk behandling. Hensikten med denne studien var ved hjelp av data fra Reseptregisteret å beskrive populasjonen av norske warfarinbrukere og kartlegge forekomsten av samtidig bruk av warfarin og de vanligste reseptpliktige analgetika og antiinflammatoriske legemidler.

\section{Material og metode \\ Reseptregisteret}

Data ble hentet fra Reseptregisteret ved Folkehelseinstituttet for tidsrommet 2004-06. Reseptregisteret inneholder informasjon om alle uthentinger av legemidler fra alle norske apotek fra 1.1.2004. Alle reseptpliktige legemidler registreres uavhengig av refusjonsordning, men legemidler utlevert til institusjoner der brukeren ikke kan identifiseres på individnivå, er ikke inkludert. Reseptregisteret inneholder informasjon om pasientens kjønn, alder, geografisk tilhørighet, forskrivers spesialitet, apotek, dato for uthenting, samt opplysninger om legemidlet som er uthentet (generisk navn, produktnavn, pakningsstørrelse, antall pakninger, anatomisk-terapeutisk-kjemisk (ATC)-kode, definerte døgndoser (DDD), og pris) (1).

\section{Pasienter}

Alle pasienter som hentet ut warfarin (Marevan) fra norske apotek i perioden 1.1.2004 til 31.12. 2006 ble inkludert. Uthentinger med mangelfull registrering av personnummer ble ekskludert da brukeren her ikke kan følges over tid. Andelen uthentinger som ble ekskludert var 2,1\% i 2004, 0,7\% i 2005 og $0,6 \%$ i 2006. Alders- og kjønnsspesifikk prevalens i ettårsperioder ble beregnet ut fra antall individer med minst én uthenting av warfarin i kalenderårene 2004, 2005 og 2006. Videre ble data vedrørende uthenting

\section{Hovedbudskap}

- I 2006 ble omtrent 80000 personer behandlet med warfarin her i landet

- Minst hver fjerde warfarinbruker får også forskrevet vanlige reseptpliktige analgetika

- Økt blødningsrisiko kan oppstå hos warfarinbrukere som også får smertestillende eller antiinflammatoriske legemidler 
Tabell 1 Behandlingstid i antall måneder for hele warfarinpopulasjonen, og for warfarinbrukere som hadde første registrerte uthenting av warfarin i 2004

\section{Behandlingstid (md) for warfarinpopulasjonen}

\begin{tabular}{lcc} 
& $\begin{array}{c}\text { Hele populasjonen } \\
(\mathbf{N}=103737)\end{array}$ & $\begin{array}{c}\text { Første uthenting av warfarin i } 2004 \\
\text { (n=72 755) }\end{array}$ \\
\hline Gjennomsnitt & 20 & 25 \\
Median [interkvartilbredde] & $24[22]$ & $29[9]$ \\
\hline 10-prosentil & 2 & 7 \\
\hline $90-$ prosentil & 33 & 34
\end{tabular}

Tabell 2 Antall warfarinbrukere (prosent av warfarinpopulasjonen) ${ }^{1}$ som hentet ut utvalgte smertestillende og antiinflammatoriske legemidler ${ }^{\dagger}$ i perioden 2004-06

\begin{tabular}{|c|c|c|c|c|c|c|}
\hline \multirow[b]{2}{*}{$\AA r$} & \multicolumn{2}{|c|}{ NSAID-preparater ${ }^{2}$} & \multicolumn{2}{|c|}{ Paracetamol ${ }^{3}$} & \multicolumn{2}{|c|}{ Svake opioider ${ }^{4}$} \\
\hline & $\mathrm{n}$ & $(\%)$ & N & $(\%)$ & $\mathrm{n}$ & $(\%)$ \\
\hline 2004 & 16289 & $(22,9)$ & 20061 & $(29,0)$ & 17608 & $(24,8)$ \\
\hline 2005 & 13109 & $(17,4)$ & 22665 & $(30,1)$ & 18704 & $(24,8)$ \\
\hline 2006 & 12459 & $(16,0)$ & 24112 & $(31,1)$ & 19501 & $(25,0)$ \\
\hline $\begin{array}{l}1 \text { Anta } \\
{ }^{2} \text { NSA } \\
{ }^{3} \text { Para } \\
{ }^{4} \text { Svak } \\
\text { ATC }\end{array}$ & $\begin{array}{l}\text { varfarin } m \\
\text { ATC-kod } \\
\text {-kode NO } \\
\text { dein komb } \\
4\end{array}$ & $\begin{array}{l}\text { inst to ut } \\
1 \text { A unntat } \\
1 \text { og ATO } \\
\text { oner ATC }\end{array}$ & $\begin{array}{l}; \mathrm{n} 2004= \\
\mathrm{min} \\
\text { 2AA59 i k } \\
\text { 2AA59, tr }\end{array}$ & $\begin{array}{l}\text { B1, n200 } \\
\text { nasjon n } \\
\text { ol ATC- }\end{array}$ & X02, dekst & ssyfe \\
\hline
\end{tabular}

av de hyppigst brukte analgetika som paracetamol og antiinflammatoriske legemidler blant warfarinbrukerne innhentet (ATCkode M01A; celekoksib, diklofenak, ibuprofen, naproksen, piroksikam), paracetamol (N02B E01) og svake opioider (N02A; paracetamol i kombinasjon med kodein, tramadol).

Anvendte kriterier for samtidig bruk av warfarin og ett eller flere av de nevnte legemidlene samsvarte med definisjonen for «concomitant medication» (5). Ifølge denne definisjonen anses samtidig bruk av legemidlene som sannsynlig dersom forskrivning ble gjort av én eller flere ulike leger til samme pasient mellom første og siste uthen-

tingsdato av warfarin i løpet av 2004, 2005 og 2006.

SPSS (Statistical Package for the Social Sciences) versjon 15.0 ble brukt som analyseverktøy.

\section{Resultater}

Totalt 103737 personer hentet ut warfarin fra norske apotek én eller flere ganger i løpet av 2004-06. Antall warfarinbrukere var 72755 (1,6\% av Norges befolkning) i 2004, $75919(1,6 \%)$ i 2005 og $79044(1,7 \%)$ i 2006. Antall brukere med kun én uthenting i løpet av 2004-06 var 3400 (3,3\%). 60\& av warfarinbrukerne var menn. Figur 1 viser aldersfordelingen for warfarinbrukerne.

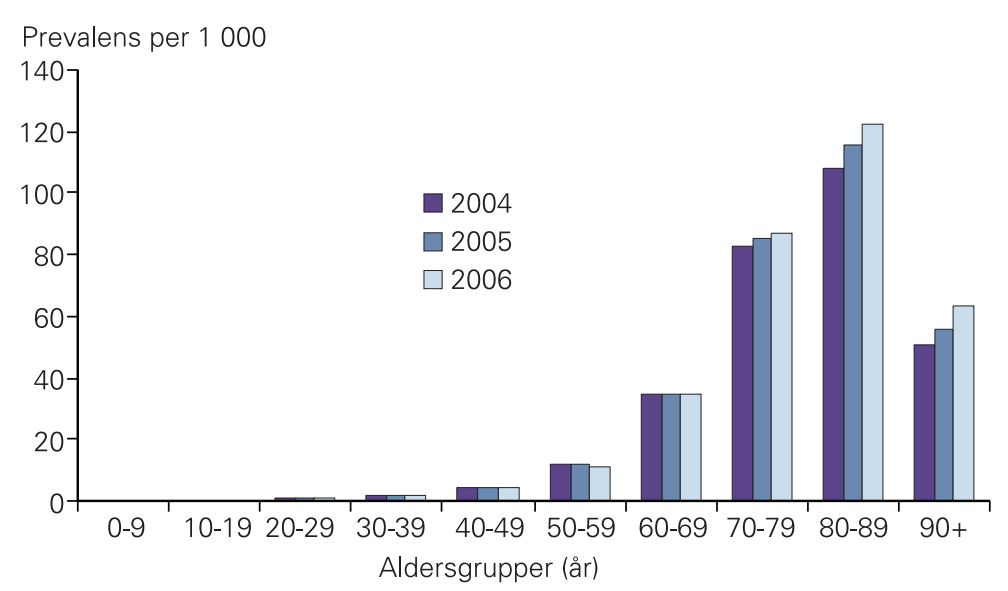

Figur 1 Ettårsprevalens lantall per 1000 innbyggerel av personer som hentet ut warfarin i 2004 , 2005 og 2006 fordelt på tiårs aldersgrupper
$93 \%$ av brukerne var eldre enn 50 år, og i aldersgruppen $80-89$ år brukte over $10 \%$ av befolkningen warfarin.

Majoriteten av pasientene ble langtidsbehandlet (tab 1). Omtrent halve populasjonen (49\%) hentet ut warfarin $\mathrm{i}$ alle tre årene, mens henholdsvis $20 \%$ og $31 \%$ hentet ut i to eller ett av årene. Blant pasienter som hadde forste registrerte uthenting av warfarin $\mathrm{i}$ 2004 , ble over $70 \%$ behandlet i alle tre årene.

$25 \%$ av warfarinbrukerne hentet ut svake opioider i hvert av årene 2004, 2005 og 2006 , mens $16-23 \%$ og $29-31 \%$ hentet ut henholdsvis NSAID-preparater og paracetamol alene eller i kombinasjon med kodein (tab 2). I perioden 2004-06 var det en reduksjon i andel warfarinbrukere som fast ble behandlet med NSAID-preparater, og en økning $\mathrm{i}$ andel paracetamolbrukere. Tabell 3 viser en mer detaljert oversikt over uthenting av ulike reseptpliktige analgetika. Diklofenak var det hyppigst brukte antiinflammatorisk midlet, mens paracetamol i kombinasjon med kodein (Paralgin forte, Pinex forte) var hyppigst brukte analgetikum blant warfarinbrukerne. I løpet av studieperioden økte bruken av paracetamol, både med henblikk på antall brukere og på gjennomsnittlig DDD per bruker, mens det ble registrert en nedgang på ca. $90 \%$ for celekoksib. Analgetika ble hentet ut gjennomsnittlig 1,5-3,4 ganger (spredning 1-116 ganger).

Forskrivning av analgetika omfattes oftest ikke av folketrygdens refusjonsordning. Reseptregisteret inneholder derfor kun sparsomme opplysninger om indikasjoner for smertestillende legemidler. Det var imidlertid mulig å identifisere kreftpasienter som hadde fått legemidler på P-resept, samt pasienter med ulike revmatiske sykdommer (blåresept, refusjonspunkt 3, 17 og 35). Inntil $5 \%$ av brukerne av svake opioider eller paracetamol hadde fått disse på P-resept. Inntil $35 \%$ av NSAID-brukerne hadde en revmatisk diagnose (hyppigst cox- og gonartrose, refusjonspunkt 35).

\section{Diskusjon}

Metodologiske forhold

Reseptregisteret innholder opplysninger om alle reseptpliktige legemidler som er hentet ut fra alle norske apotek til individuelle pasienter. Reseptregisteret gir ingen opplysninger om faktisk bruk av medikamentene; kun uthenting fra apotek. Det er heller ikke mulig å skille mellom kontinuerlig bruk av et legemiddel (som warfarin) og kortere behandlingsperioder mellom to uthentinger (som for eksempel warfarin gitt forut for elektrokonvertering). Når data er innsamlet på denne måten, elimineres risiko for seleksjonsskjevhet og faren for at pasientene ikke husker tidligere legemiddeleksponering (recall bias) (1).

Andelen uthentinger som manglet personnummer, lå noe høyere i 2004 enn i 2005 og 2006, trolig på grunn av at 2004 var første 
registreringsår og at det tok tid før registreringsrutinene var fullt innarbeidet (1). Forskjellene $i$ andel ekskluderte uthentinger kan ha bidratt til at ettårsprevalensen for warfarinbruk lå noe lavere i 2004 enn i 2005 og 2006

Samtidig bruk ble registrert dersom et analgetikum eller antiinflammatorisk legemiddel ble hentet ut i perioden mellom forste og siste uthenting av warfarin i ett kalenderår. En så vid definisjon kan medføre en overestimering av komedikasjon, men ble likevel valgt da warfarin er et legemiddel det ofte kan antas brukes kontinuerlig. Denne antakelsen støttes av at kun 3,3\% av populasjonen hentet ut warfarin bare én gang i studieperioden. En strengere definisjon av samtidig bruk ville medført eksklusjon av tilfeller der warfarin og analgetika er forskrevet av forskjellige leger og på forskjellige tidspunkter (5).

\section{Warfarinpopulasjonen}

Antall warfarinbrukere var høyere enn tidligere anslått. Reseptregisteret bygger på alle uthentede resepter fra alle norske apotek, og gir et eksakt brukerantall. Prevalensen av warfarinbruk økte gjennom studieperioden. Økt vekt på forekomst av atrieflimmer og bruk av warfarin som slagprofylakse hos slike pasienter kan ha bidratt til dette (6), i tillegg til bedre registreringsrutiner i Reseptregisteret (1).

Majoriteten av warfarinbrukerne i Norge er over 70 år, og det er flest menn. Reseptregisteret omfatter ikke legemidler brukt $\mathrm{i}$ institusjoner, dette er nok noe av forklaringen på den markerte nedgangen i prevalens av warfarinbruk etter passerte 90 år.

\section{Samtidig bruk av warfarin og analgetika}

Flertallet av pasientene som brukte warfarin og som det ble rapportert om blødningskomplikasjoner for i 2003-06, brukte ett eller flere legemidler i tillegg til warfarin (7). I denne studien hentet minst hver fjerde warfarinbruker ut et analgetikum eller et antiinflammatorisk middel én eller flere ganger i studieperioden. Dette er i samsvar med funn fra en undersøkelse av legemiddelrelaterte problemer blant pasienter innlagt i sykehus (8), men langt høyere enn observert $\mathrm{i}$ en studie fra norsk allmennpraksis der kun $0,3 \%$ av populasjonen over 70 år hadde fått forskrevet warfarin og NSAID-preparater samtidig (9). Imidlertid var det der ikke angitt hvilke kriterier som ble lagt til grunn for «samtidig bruk». Kriteriene kan ha vært strengere enn i vår studie. Forekomsten av samtidig bruk i de to studiene kan av metodologiske årsaker derfor ikke sammenliknes.

De hyppigst uthentede analgetiske og antiinflammatoriske substansene $\mathrm{i}$ vår studie var diklofenak, paracetamol og kodein. Diklofenak var mer enn dobbelt så hyppig brukt som ibuprofen, naproksen og piroksikam. Forbrukstallene for ibuprofen og na-

Tabell 3 Antall warfarinbrukere (prosent av warfarinpopulasjonen) ${ }^{1}$ med minst to uthentinger av de mest brukte NSAID-preparatene, paracetamol eller svake opioider på resept i perioden 2004-06, fordelt på type legemiddelsubstans, år, gjennomsnittlig antall ordinasjoner og antall definerte døgndoser (DDD) (4)

\begin{tabular}{|c|c|c|c|c|c|c|}
\hline \multirow[b]{2}{*}{$\begin{array}{l}\text { Type anal- } \\
\text { getikum }\end{array}$} & \multirow[b]{2}{*}{ Antall (\%) } & \multicolumn{3}{|c|}{ Ordinasjoner } & \multicolumn{2}{|c|}{ DDD } \\
\hline & & $\begin{array}{l}\text { Gjennom- } \\
\text { snitt }\end{array}$ & Median & $\begin{array}{c}\text { Variasjons- } \\
\text { bredde }^{2}\end{array}$ & Antall & $\begin{array}{l}\text { Gjennom- } \\
\text { snitt }\end{array}$ \\
\hline \multicolumn{7}{|c|}{ NSAID-midler } \\
\hline \multicolumn{7}{|l|}{ Diklofenak } \\
\hline 2004 & $3045(4,3)$ & 1,7 & 1 & 14 & 139614 & 45,9 \\
\hline 2005 & $4507(6,0)$ & 1,8 & 1 & 23 & 217005 & 48,1 \\
\hline 2006 & $5005(6,4)$ & 1,8 & 1 & 25 & 242663 & 48,5 \\
\hline \multicolumn{7}{|l|}{ Ibuprofen } \\
\hline 2004 & $1772(2,5)$ & 1,7 & 1 & 17 & 100066 & 56,5 \\
\hline 2005 & $2050(2,7)$ & 2,2 & 1 & 21 & 119705 & 58,4 \\
\hline 2006 & $2108(2,7)$ & 1,8 & 1 & 25 & 131950 & 62,6 \\
\hline \multicolumn{7}{|l|}{ Naproksen } \\
\hline 2004 & $1248(1,8)$ & 1,8 & 1 & 5 & 105315 & 84,4 \\
\hline 2005 & $1542(2,0)$ & 1,9 & 1 & 20 & 141868 & 92,0 \\
\hline 2006 & $1433(1,8)$ & 1,9 & 1 & 21 & 126853 & 88,5 \\
\hline \multicolumn{7}{|l|}{ Piroksikam } \\
\hline 2004 & $1179(1,7)$ & 1,5 & 1 & 14 & 69396 & 58,9 \\
\hline 2005 & $1784(2,4)$ & 1,6 & 1 & 19 & 108342 & 60,7 \\
\hline 2006 & $1737(2,2)$ & 1,6 & 1 & 41 & 102402 & 59,0 \\
\hline \multicolumn{7}{|l|}{ Celekoksib } \\
\hline 2004 & $4794(6,7)$ & 2,3 & 2 & 21 & 858541 & 179,1 \\
\hline 2005 & $1606(2,1)$ & 2,2 & 1 & 47 & 225935 & 140,7 \\
\hline 2006 & $558(0,7)$ & 2,5 & 1 & 25 & 61963 & 111,0 \\
\hline \multicolumn{7}{|l|}{ Anilider } \\
\hline \multicolumn{7}{|c|}{ Paracetamol } \\
\hline 2004 & $8925(12,6)$ & 2,8 & 2 & 32 & 550418 & 61,7 \\
\hline 2005 & $10952(14,5)$ & 3,0 & 2 & 51 & 739661 & 67,5 \\
\hline 2006 & $12320(15,9)$ & 3,1 & 2 & 51 & 887689 & 72,1 \\
\hline
\end{tabular}

\section{Svake opioider}

Kodein ${ }^{3}$

\begin{tabular}{crrrrrr}
2004 & $15278(21,5)$ & 3,4 & 2 & 95 & 990776 & 64,9 \\
2005 & $16068(21,3)$ & 3,4 & 2 & 116 & 1035609 & 64,5 \\
2006 & $16460(21,1)$ & 3,4 & 2 & 103 & 1070827 & 65,1 \\
\hline Tramadol & & & & & & \\
2004 & $3324(4,7)$ & 2,6 & 1 & 63 & 128398 & 38,6 \\
2005 & $3842(5,1)$ & 2,7 & 1 & 82 & 152973 & 39,8 \\
2006 & $4636(6,0)$ & 2,8 & 1 & 65 & 185299 & 40,0
\end{tabular}

${ }^{1}$ Antall brukere av warfarin med minst to uthentinger; n2004 $=71081$, n2005 $=75$ 380, n2006 $=77857$

2 Maksimum minus minimum antall ordinasjoner

${ }^{3}$ Kodein i kombinasjon med paracetamol

proksen representerer imidlertid et absolutt minimum av reell bruk, siden disse i motsetning til diklofenak også er tilgjengelige uten resept. Over $40 \%$ av salget av ibuprofen og paracetamol skjer via dagligvarehandelen (10). Opplysninger om samtidig bruk av warfarin og NSAID-preparater tilgjengelig uten resept vil bare kunne innhentes ved hjelp av spørreundersøkelser eller liknende. Det er kjent at warfarinbrukere ofte unnlater å informere legen om at de bruker reseptfrie legemidler, natur(lege)midler o.1, og at de heller ikke informerer apoteket om at de bruker warfarin ved kjøp av slike midler (11). Dette er generelt betenkelig siden mange slike preparater enten kan øke blødningsrisikoen eller bidra til behandlingssvikt (økt tromboserisiko).

Paracetamol i terapeutiske doser kan øke INR-verdien og dermed risikoen for blødninger. Interaksjonen er av farmakokinetisk karakter, og kan forklares med at en metabolitt av paracetamol ( $\mathrm{N}$-acetylparabenzoquininimin) hemmer vitamin K-avhengig gam- 
makarboksylase (12). Det totale forbruket av paracetamol i populasjonen kan antas å være høyere enn vist her pga. høy tilgjengelighet uten resept. Reseptbelagt paracetamol var hyppig brukt i kombinasjon med kodein. Kodein metaboliseres via CYP2D6 (4), et enzym som ikke er involvert i warfarinmetabolismen, og så vidt oss bekjent foreligger det ikke opplysninger om at kodein påvirker effekten av warfarin. Kodein finnes også som monopreparat (Kodein tabletter $25 \mathrm{mg}$ ) og kan eventuelt være et alternativ dersom periodisk bruk av paracetamol og kodein i kombinasjon medfører ustabilt INR-nivå.

Tramadol er et lite brukt opioid sammenliknet med kodein, men bruken er økende. Økt INR-verdi ved samtidig bruk av warfarin og tramadol er beskrevet $(4,13)$. Mekanismen er ikke kjent, men en teori er at metabolismen av tramadol hos pasienter med lav CYP2D6-aktivitet, noe som forekommer hos ca. $10 \%$ av kaukasiere, skyves over mot CYP3A4, som også metaboliserer R-warfarin. Det kan dermed oppstå konkurranse om binding til enzymets aktive sete. Ved bruk av tramadol sammen med warfarin bør derfor INR-nivået monitoreres.

Samtidig behandling med warfarin og antiinflammatoriske midler anbefales generelt ikke, men vil likevel ofte være aktuelt, for eksempel ved kreft eller revmatiske lidelser. Eldre er generelt utsatt for legemiddelbivirkninger, og kombinasjonen warfarin/NSAIDpreparater er kanskje ekstra risikabel hos de eldste. Selektive cox-2-hemmere er antatt å gi færre gastrointestinale blødninger enn uselektive NSAID-preparater, men denne gevinsten er ikke sett blant warfarinbrukere (4). Det er derimot beskrevet flere tilfeller av blødninger og økt INR-verdi hos warfarinbrukere som får celekoksib $(14,15)$. En mulig mekanisme her kan være konkurranse om bindingssetet på CYP2C9, som metabo- liserer både S-warfarin og celekoksib (14). Celekoksib er dessuten en hemmer av dette enzymet (14). Det ble i denne studien observert en kraftig nedgang i antall uthentinger av celekoksib fra 2004 til 2006, trolig mest på grunn av at preparatet ble tatt ut av blåreseptordningen 1.5. 2005. Antall uthentinger av uselektive NSAID-preparater var relativt stabilt i studieperioden. Unntaket her var diklofenak, der det ble observert en økning i antall uthentinger i løpet av de tre årene. Diklofenak kan muligens være et gunstig førstevalg hos warfarinbrukere med behov for antiinflammatorisk behandling, da substansen er mer cox-2-selektiv og gir mindre risiko for gastrointestinale komplikasjoner enn de fleste andre uselektive NSAID-preparatene (16).

\section{Konklusjon}

Antall warfarinbrukere i Norge var i 2006 underkant av 80000 . Minst en firedel av warfarinbrukerne får samtidig forskrevet analgetiske eller antiflammatoriske midler som har interaksjonspotensial med warfarin, noe som er uheldig med tanke på blødningsrisiko. Det er ikke kjent i hvilket omfang warfarinbrukere også bruker analgetika eller antiinflammatoriske midler unntatt fra reseptplikten. Med unntak av kodein kan alle de vanligst brukte analgetika og NSAIDpreparater øke effekten av warfarin, med eller uten påvirkning av INR-nivået. Både helsepersonell og pasienter må være spesielt oppmerksomme på tegn på økt effekt av warfarin.

Oppgitte interessekonflikter: Ingen

\section{Litteratur}

1. Furu K. Establishment of the nationwide Norwegian Prescription Database (NorPD) - new opportunities for research in pharmacoepidemiology in Norway. Nor J Epidemiol 2008; 18: 129-36.
2. Breen $A B$, Vaskinn TE, Reikvam $\AA$ et al. Warfarinbehandling og blødninger. Tidsskr Nor Lægeforen 2003; 123: 1835-7.

3. Hirsch J, Dalen JE, Anderson DR et al. Oral anticoagulants: mechanism of action, clinical effectiveness and optimal therapeutic range. Chest 2001; 119 (suppl 1): 8-21

4. Knijff-Dutmer EA, Schut GA, van de Laar MAJF. Concomitant coumarin-NSAID therapy and risk for bleeding. Ann Pharmacother 2003; 37: 12-6.

5. Tobi H, Faber A, van den Berg PB et al. Studying co-medication patterns: the impact of definitions. Pharmacoepidemiol Drug Saf 2007; 16: 405-11.

6. Bratland B. Warfarinbehandling i allmennpraksis. Tidsskr Nor Lægeforen 2006; 126: 162-5.

7. Narum S, Solhaug V, Kringen MK et al. Blødninger knyttet til warfarinbruk: rapporter fra bivirkningsregisteret i 2003-2006. Nor J Epidemiol 2007; 17: 36.

8. Nordsveen M, Eek AK, Blix HS et al. Co-prescribing of warfarin and NSAIDs/aspirin - frequency and problems. Nor J Epidemiol 2007; 17: 35.

9. Brekke M, Rognstad S, Straand J et al. Pharmacologically inappropriate prescriptions for elderly patients in general practice: how common? Scand J Prim Health Care 2008; 26: 80-5

10. $\emptyset \mathrm{kning}$ i salg av reseptfrie legemidler utenom apotek 2004-2006. Oslo: Folkehelseinstituttet,2007. www.fhi.no/artikler?id=64244 (25.7.2008).

11. Warfarin-pasienter informerer ikke. Dagens Medi$\sin$ 9.9.2004. www.dagensmedisin.no/nyheter/ VisUtskrift.asp?Artld=4904 (25.7.2008).

12. Thijssen HH, Soute BA, Vervoort LM et al. Paracetamol (acetaminophen) warfarin interaction: NAPQI, the toxic metabolite of paracetamol, is an inhibitor of enzymes in the vitamin K cycle. Thromb Haemost 2004: 92: 797-802.

13. Dumo PA, Kielbasa LA. Successful anticoagulation and continuation of tramadol therapy in the setting of a tramadol-warfarin interaction. Pharmacotherapy $2006 ; 26: 1654-7$

14. Stading JA, Skrabal MZ, Faulkner MA. Seven cases of interaction between warfarin and cyclooxygenase-2 inhibitors. Am J Health Syst Pharm 2001; 58: 2076-80.

15. Malhi H, Atac B, Daly AK et al. Warfarin and celecoxib interaction in the setting of cytochrome $\mathrm{P} 450$ (CYP2C9) polymorphism with bleeding complication. Postgrad Med J 2004; 80: 107-9.

16. Rang HP, Dale MM, RitterJM, red. Rang and Dales pharmacology. 6. utg. Edinburgh: Churchill Livingstone Elsevier, 2007: 233.

Manuskriptet ble mottatt 11.8. 2008 og godkjent 19.3. 2009. Medisinsk redaktør Åslaug Helland. 